\title{
THE ACTS AND ORDINANCES
}

OF

\section{THE EASTLAND COMPANY}


PRINTED BY

BPOTHE WOODE $\triangle N D$ CO. LTD., NEW-Bר REET BQUARE LONDON 
THE

\section{ACTS AND ORDINANCES \\ OF}

\section{THE

EDITED FOR THE ROYAL HISTORICAL SOCLETY

FROM THE ORIGINAL MUNIMENTS OF THE GILD OF

MERCHANT ADVENTURERS OF YORK

BY

MADD SELLERS

FORMGELY OF NEWNHAM COLLEGE, CAMBAIDGE

LONDON

OFFICES OF THE ROYAL HISTORICAL SOCIETY

8 OLD SERJEANTS' INN, CHANCERY LANE, W.C.

1906 


\section{CONTENTS}

INTRODUOTION :

PAGE

The-Eastland Company of York: The Charter . . . . ix

Chief Exports and Imports . . . . . . . . . $x$

Geographical Limits . . . . . . . . . . . xi

Candidates eligible . . . . . . . . . . . . . . xii

Officers of the Company $\quad . \quad$. $\quad . \quad$. $\quad . \quad . \quad . \quad . \quad$ xiii

Governors and Deputies in London . . . . . . . ib.

Provincial Deputies and Courts . . . . . . . xiv

The Company's legal rights and powers. . . . . . . iz.

Relations of Eastland Merchants and Merchant Adventurers . xvi

Records of the Acts and Ordinances of the Eastland Company . xviii

Regulations of its Courts . . . . . . . . IX

Duties of the Officers: Secretary, Treasurer, Assistants . . xxi

The Arms of the Company . . . . . . . . . ib.

Election and treatment of officials . . . . . . . sxiii

Regulations for Apprentices . . . . . . . . . . . . xxiv

Rules affecting masters of the Company's ships . . . . Xxv

Central Court and Court beyond seas . . . . . . xxvi

Right of appeal . . . . . . . . . . . . xxvii

Assistants for special service . . . . . . . . . . xxviii

Comparison of Merchant Adventurers and Eastland Merchants xxxi

Their occsional joint action . . . . . . . xxxiii

Shsred officials $. \quad . \quad . \quad . \quad . \quad . \quad . \quad . \quad . \quad . \quad$ sxxiv

Many merchants members of both Companies . . . . Xxxv

Eastland Company favoured by royalty . . . . . . . xxxvii

Charter renewed by James I. and Charles I. . . . . xxxix

Dantzic as an outport : difficulties thence encountered . . . xl

Charles I. and the Companies . . . . . . . xliii

Effects of the Civil War. . . . . . . . . . xliv

Subsidy demanded by Poland from Eastland Merchants . . xlv

Trouble with Denmark . . . . . . . . . xlvi

Cromwell's treatment of the Company . . . . . xlvii 
INTropUCrion (continued)-

Confirmation of Charter by Charles II. . . . . . . xlviii Difficulties in 1673

Decay of the Eastland Company . : : . . . . . 1

Gradual decrease of trade . . . . . . . . . . . li

Details of exports and imports . . . . . . . . lii

Sale prices of Eastland products $\quad . \quad$. $\quad . \quad . \quad . \quad . \quad$ liv

Complaints against Eastland Company . . . . . . lv

Their defence . . . . . . . . . . . . l lvii

Causes of decay of trade $\quad . \quad$. $\quad . \quad . \quad . \quad . \quad . \quad . \quad$ lviii

The establishment of Provincial Courts . . . . . lx

Success of northern Residences . . . . . . . . . Ixi

Local Courts and their work . . . . . . . Ixiii

Strong Puritan feeling of the Company . . . . . . lxiv

York's jealousy of Hull . . . . . . . . $\mathrm{lxv}$

The Eastland Merchants in Newcastle . . . . . . 1xvii

York's jealousy of Leeds . . . . . . . . lxix

Struggle between coast towns and London . . .. '. . Ixx

Grievances of provincial Courts . . . . . . . Ixxii

Northern jealousy of London. . . . . . . . l l exv

Dispute between the York and London Courts . . . . Ixxvi

End of the dispute . . . . . . . . . . 18xxi

Other difficulties $. \quad . \quad . \quad . \quad . \quad . \quad . \quad . \quad . \quad$. Ixxxii

The final dispute . . . . . . . . . . Ixxxvii

Acts and Ordinances of the Eastuand Company . . . . . . 1

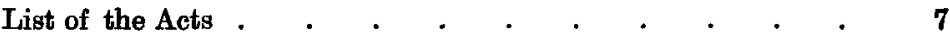

Details of the varions Acts . $\quad . \quad$. $\quad . \quad$. $\quad . \quad$. . 11

Extracts from the Court Book of the York Eastland Company ${ }^{\cdot} 71$ APPENDIX :

1. Charter of Henry IV. . . . . . . . . 141

2. Charter of Eastland Merchants [Queen Elizabeth's] - . 142

3. Proclamation of James I. (21 July, 1622) prohibiting Eastland Commodities except those traded by Freemen of that Company . . . . . . . . . . .

4. Proclamation of Charles I. (7 March, 1629) renewing the former Proclamation of $1622 \quad \cdot \quad \cdot \quad . \quad . \quad . \quad . \quad 153$

5. Act of Privy Council on behalf of the Fastland Company (5 Jnne, 1616) • • • • • . • • • • • • • 155

6. Agreement between Christian the $4^{\text {th }}$ of Denmark and the Lords and Commons of the Kingdom of England . . . 159 